Makarczuk Anna. Body posture and competitive sport - a review of selected studies. Journal of Education, Health and Sport. 2020;10(12):192-200. eISSN 2391-8306. DOI http://dx.doi.org/10.12775/JEHS.2020.10.12.019

https://apcz.umk.pl/czasopisma/index.php/JEHS/article/view/JEHS.2020.10.12.019

https://zenodo.org/record/4398831

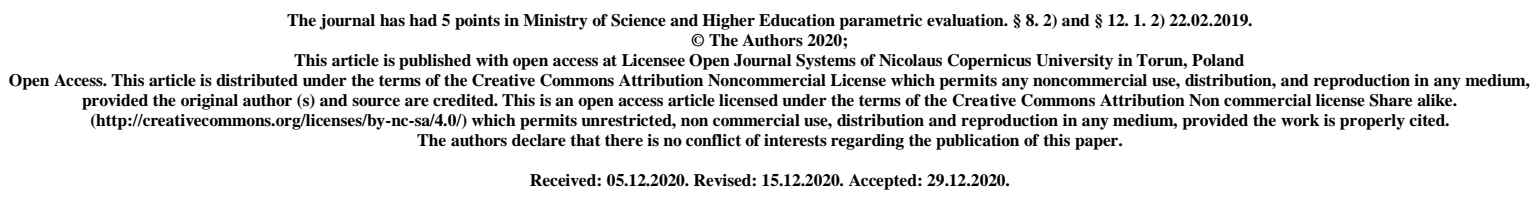

\title{
Body posture and competitive sport - a review of selected studies
}

\author{
Anna Makarczuk ${ }^{1}$ \\ University of Lodz, Faculty of Educational Sciences, The Education Center for Sport \\ Pedagogists, mail: anna.makarczuk@now.uni.lodz.pl
}

\section{Summary}

Increased motor activity does not unequivocally affect the incidence rates of correct and incorrect postures and practising physical exercise does not ensure good posture. Onesided load that occurs in competitive sports affects the formation of physiological curves of the spine, most often causing their deepening. In disciplines characterised by asymmetry of movements, lateral curvatures of the spine occur more often than in others.

In order to achieve a posture considered to be correct, in addition to general development and sports result-oriented exercises, it is necessary to consciously shape and correct it. ${ }^{2}$ This is especially important when working with children and youth. It should be remembered that the susceptibility of the spine to changes in the shape of curves is different and depends on age. Wolański studied the so-called critical periods of posturogenesis among Warsaw youth and stated that the most dangerous age is between 12 and 15 for boys and between 10 and 13 for girls. ${ }^{3}$ It is then that the thoracic and lumbar curves are characterised by the greatest lability. They are very often deepened, which the author explains, among others changes in body proportions, i.e. elongation of the lower limbs. The commencement of professional training often takes place during this period, therefore, compensatory exercises should be its permanent element.

Key words: competitive sport, body posture

\footnotetext{
${ }^{1}$ University of Lodz, Faculty of Educational Sciences, The Education Center for Sport Pedagogists, mail: anna.makarczuk@now.uni.lodz.pl, ORCOD: 0000-0001-8668-0737.

${ }^{2}$ Chobocka E. Ćwiczenia wyrównawcze dla hokeistów, siatkarzy i piłkarzy nożnych. Wychowanie Fizyczne i Higiena Szkolna. 1988; 6: 187 - 190. Polish.

${ }^{3}$ Wolański N. Krytyczny wiek w kształtowaniu się postawy ciała. Chirurgia Narządów Ruchu. 1958; 23(2): 129

-133 . Polish.
} 


\section{Introduction}

The ability of the human body to adapt to the conditions of increased physical effort and coordination skills depend on many factors. One is the body posture ${ }^{4}$. The correct positioning of the feet and knees, the shape of the physiological curves of the spine and the symmetry of the torso have a direct impact on human performance.

Body posture is a 'way to keep upright position', but it does not reflect the complexity of the issue. Attempts to define the correct posture have been made many times and have resulted in many different terms, and each one emphasizes a different characteristic element. Wolański was one of the first Polish researchers to formulate a definition that, despite the passage of time, seems to be correct: "A right posture should be understood as a posture consistent with the dynamics of human development in a given period of ontogenesis ...". 5 The more well-known also include the definitions of Malinowski from 1985, Zeyland Malawka from 1992 and Kasperczyk from $1995 .{ }^{6}$

Training, as a strong stimulus for the body, affects the functioning of most systems and organs. The most important changes occur in the muscular system, where there is an increase in muscle mass and changes in the distribution of muscle tensions. It may be reflected in the posture of the human body, indirectly causing different positions of individual bone segments. Considering the fact that specialized training is started in the period of intense growth and development, its impact on the athlete's body is very strong. ${ }^{7}$ These issues are a frequent topic of research by doctors, physiologists and therapists, and the data from them provide knowledge, thanks to which trainers and coaches can more effectively counteract the negative effects of increased training loads in various sports.

Below is a review of selected studies on changes in individual elements of the human musculoskeletal system, defining the correct body posture, and taking place under the influence of sports training.

\section{The influence of sports training on the shape of the physiological curves of the spine}

It can be assumed that a specific motor specialization influences a posture in a way characteristic of it. Confirmation should be sought in the analysis of the shape of the spine of highly classified players with long training experience, representing various sports disciplines. Research by Smolik and Stokłosa shows that handball players are characterized by large thoracic kyphosis with a low peak and low lumbar lordosis ${ }^{8}$. More recent studies partially confirm these changes- female handball players exhibited a much higher incidence of kyphotic posture compared to girls who did not train 9 .

\footnotetext{
${ }^{4}$ Wolański N. Rozwój biologiczny człowieka. PWN, Warszawa. 2005. 264 - 271. Polish.

${ }^{5}$ Kasperczyk T. Wady postawy ciała. Wyd. Kasper. Kraków. 1995. 9 - 11. Polish.

${ }^{6}$ Zeyland - Malawka E. O kryteriach oceny postawy. (W:) Postawa ciała człowieka i metody jej oceny. (red.) J. Ślężyński. AWF Katowice. 1992. Polish.

${ }^{7}$ Osiński W. Antropomotoryka. AWF Poznań. 2003. 67 - 72. Polish.

${ }^{8}$ Smolik A, Stokłosa E. Zmiany kształtu kręgosłupa u sportowców. Kultura Fizyczna. 1959; 5: 23 - 36. Polish.

${ }^{9}$ Barczyk - Pawelec K, Giemza C, Jastrzębska R, Hawrylak A, Kaczkowska A. Kształt krzywizn przednio tylnych kręgosłupa w płaszczyźnie strzałkowej dziewcząt uprawiających piłkę ręczną. Acta Bio - Optica et Informatica Medica. 2012; 4 (18): 237 - 242. Polish.
} 
This may be due to the specificity of sports games and training, a significant part of which is running with the ball in a forward leaning position. Anyway incorrect body posture was found to prevail in both handball players and girls from the control group.

Fencers have a large thoracic kyphosis and a large slope of the lumbosacral segment. Hockey players, in turn, have a high peak of kyphosis. Speed skaters are characterized by a small kyphosis and a high inclination of the lumbosacral section. Weightlifters have a small kyphosis and a high peak of lordosis. Among judokas, on the other hand, there is a large slope of the lumbosacral section and a low-located lordosis. The significant differences concern mainly the position (high or low) of the peaks of thoracic kyphosis and lumbar lordosis. The slope of the sections of the spine that make up the thoracic kyphosis differs between handball players, fencers, hockey players, and judo athletes who have higher measured values for these angles, and speed skaters and powerlifters who have lower kyphosis. The slope of the lumbosacral spine is generally large in all groups of the athletes ${ }^{10}$.

The features of the spine, typical of the type of sport, do not always reflect the shape it takes during the most frequently performed movements and training positions. One could see such a mechanism of their formation, e.g. in the case of weightlifting, where the small kyphosis and high location of the peak of lordosis, characteristic for competitors of this discipline, reflect the shape of the spine while lifting the barbells, but in skaters a small kyphosis and a large slope of the lumbosacral section are a contradiction of their typical kyphoto-flexion working position. The high position of the peak of kyphosis in the posture of hockey players resembles the shape of the upper part of the spine in the figure of skaters, while the very low peak of lordosis in judokas seems to be explained by the technique of this discipline. Perhaps the location of the top of the lordosis is related to the location of the centre of gravity - in judokas, its low location is advantageous, while in weightlifters characterised by an extensive, well-muscled shoulder girdle and chest, the centre of gravity may be higher and hence the high position of the top of the lordosis ${ }^{11}$.

Changes in the shape of physiological curves of the spine can also be observed in swimmers. ${ }^{1213}$ A clear deepening of the thoracic kyphosis angle and a reduction in lumbar lordosis occur in competitors swimming the breaststroke as well as butterfly and crawl ones. The backstroke does not visibly affect the depth of kyphosis but increases its range, the lordosis is shortened and made shallow.

In the studies of Wojtków, Korcz i Szotek ${ }^{14}$ from 2011, conducted on a group of sport shooting competitors, statistically significant changes in the shape of thoracic kyphosis were observed - its deepening, and the shape of lumbar lordosis. Compared to men, these deviations were greater in the group of women, especially in the lumbosacral part.

\footnotetext{
${ }^{10}$ Tamże

${ }^{11}$ Chobocka E. Ćwiczenia wyrównawcze dla hokeistów, siatkarzy i piłkarzy nożnych. Wychowanie Fizyczne i Higiena Szkolna. 1988; 6: 187 - 190. Polish.

${ }^{12}$ Iwanowski W. Pływanie korekcyjno - lecznicze w przypadkach bocznych skrzywień kręgosłupa. Wyd. Uniwersytetu Szczecińskiego. 1997. 47 - 51. Polish.

${ }^{13}$ Stasiak J, Wierzbicka A. Kształtowanie się fizjologicznych krzywizn kręgosłupa u dzieci 8 - letnich, uprawiających pływanie na tle rówieśników niepływających. Lider. 1992; 9: 64 - 72. Polish.

${ }^{14}$ Wojtków M, Korcz K, Szotek S. Ocena postawy ciała i symetrii obciążenia stóp u zawodników uprawiających strzelectwo sportowe. Aktualne Problemy Biomechaniki. 2016; 10: 91 - 98. Polish.
} 
The importance of the shape of the spine as a factor in achieving good athletic performance varies from one sport to the next. It probably plays a greater role in forms of sports movement where the body is in an upright position. For example, for handball players and fencers, large curves of the spine can provide better body cushioning and bounce, and small curves in powerlifters prevent vertebrae from slipping while lifting the barbells. For skaters and hockey players, whose typical working positions change the arrangement of the spine bends, as well as for judokas, for whom the shape of the spine is constantly changing in training and sports combat, the size and location of its curves does not seem to play a major role. The features of the shape of the spine that characterise these disciplines, i.e. low kyphosis in skaters, high location of the peak of kyphosis in hockey players and particularly low location of the peak of lordosis in judokas, may have an indirect meaning for the structure of movements that determine good sports results. Particularly frequent occurrence of similar features of the shape of the spine among the selected (in terms of the length of experience and achievements) players of various disciplines allows for assuming these features as favourable to practicing a given field of sport.

At the same time, many sports disciplines not only change a person's posture, but can also deform it, leading to its defects.

The comparison of postures evaluations of players from various sports disciplines and university students who do not practice sports in a competitive manner, shows that the incidence rate of incorrect postures among students, speed skaters and weightlifters reaches level of $20 \%$, while in the remaining groups of players, i.e. football, fencers, hockey ones, judokas, the postures evaluated as incorrect accounts for about $30 \%$ of the total ${ }^{15}$.

The round back is a common defect among basketball players. During training and matches, players are forced to lower their positions and lean forward. The arms also point forward, which keeps the scapulars away from the spine line. Both of these elements, recorded during many training sessions and matches, result in deepening of kyphosis and the scapular winging. ${ }^{16}$

The change of the body can also be observed in long training cyclists. In most of them, the thoracic kyphosis angle is significantly increased and the lumbar lordosis angle is decreased. As a result, the defect often found in this group of athletes is total kyphosis.

Interesting information on body posture is provided by a 2004 study among 380 young athletes (aged 11-15), training the running mostly. The comparative group was the population of over 1,200 children from Polkowice town. The analysis of the results showed decreasing the incidence of normal postures in the range between 11 and 15 years of age. Such a situation was observed in both gender groups and applied to both children with early sports specialization and non-training groups. In the junior grades. at the age of 11 and 12, children from the groups of early sports specialization were more often characterised by the correct body posture than their untrained peers. In the following grades, aged 13, 14 and 15, the percentages of correct postures were generally lower in children participating in sports than in the non-training population.

\footnotetext{
${ }^{15}$ Chrzanowska M, Chojnacki K. Z badań nad stanem postawy ciała i sprawności fizycznej studentów. Kultura Fizyczna. 1976; 12; $24-36$. Polish.

${ }^{16}$ Makarczuk A, Kaźmierczak A. Wpływ sportu wyczynowego na postawę ciała. Aktywność ruchowa ludzi w różnym wieku. PTNKF Szczecin. 2004; 8: 248 - 254. Polish.
} 
Both in the group of training children and in the control group, in boys, among abnormal postures, kyphotic postures were significantly more frequent, and in girls - lordotic ones. ${ }^{17}$

Volleyball, apart from its kyphotising effect, is also conducive to knee valgus. Players make many jumps, often on hard ground, they move in a low position with bent and slightly set lower limbs, which causes the knees to turn inwards and they are incorrectly loaded. The volleyball player's feet are set similarly in this situation. Overloading the medial edge of the foot promotes the formation of longitudinal flat feet. ${ }^{18}$ However, studies conducted in 2008 among 36 boys training volleyball, aged 15-16 years did not confirm the occurrence of the described changes. ${ }^{19}$ There were no significant differences in body posture compared to the untrained group. Athletes with greater training experience showed greater muscle strength in the area of the back muscles and less kyphosis of the thoracic section. The researchers found that the less frequent occurrence of deepening thoracic kyphosis in older players and their greater muscle strength confirms the legitimacy of implementing strength training in the process aimed at strengthening not only those muscles that are of particular importance during the main game, but also those that are responsible for maintaining the correct upright posture. This training should be used especially in the periods of ontogenetic changes in the size of the physiological curvature of the spine.

Among sports climbing athletes, the kyphotic position of the upper spine is very characteristic. Climbing over overhang requires considerable strength and endurance in the upper limbs and the shoulder girdle. The back muscles are very strong, but mostly work in a distance from the muscle insertions. Again the pectoral muscles are working in closer positions, like the rectus abdominis. As a result, the shoulders are pulled forward and the chest is positioned by the exhalation. These changes may become permanent, leading to the development of thoracic hyperphosis. ${ }^{20}$

The research of Świderska shows that in dancers, whose professional activity can certainly be compared to professional training of athletes, there are numerous cases of shallowing or even disappearance of both anterior-posterior curves of the spine. These are the so-called flat back. This state is explained by the fact that dancers, from an early age, have a very strong muscular corset in hyper-correction and elongation positions of the spine ${ }^{21}$.

\section{Selected sports disciplines and their influence on lateral axis deviations of the spine}

The analysis of athletes of the spine in the frontal plane discloses a common, small variations spinous process line from the vertical. ${ }^{22}$ The curvatures are usually left-sided with the location of the apex in the thoracic or thoracic-lumbar region. Scoliosis occurs in most fencers where a significant lowering of the shoulder of the exercising limb is typical.

\footnotetext{
${ }^{17}$ Fugiel J, Sławińska T. Postawa ciała dzieci wczesnej specjalizacji sportowej. Antropomotoryka. 2011; 53: 79 83. Polish.

${ }^{18}$ Makarczuk A, Kaźmierczak A. Wpływ sportu wyczynowego na postawę ciała. Aktywność ruchowa ludzi w różnym wieku. PTNKF Szczecin. 2004; 8: 248 - 254. Polish.

${ }^{19}$ Tabor P, Olszewska E, Trzcińska D, Madej A, Ostrowska E, Iwańska D, Mastalerz A, Urbanik C. Postawa ciała i siła wybranych grup mięśni młodych siatkarzy. Medycyna Sportowa. 2012; 1(4), Vol. $28: 27$ - 37. Polish. ${ }^{20}$ Sonelski W, Sas - Nowosielski K. Trening wspinaczkowy dzieci i młodzieży. (W:). Sonelski W. Sas Nowosielski K. Wspinaczka halowa. Vademecum. Polski Związek Alpinizmu. Warszawa. 1999. 61 - 68. Polish. ${ }^{21}$ Świderska K. Zdrowie tancerzy. Warszawa; 1995. 117 - 124. Polish.

${ }^{22}$ Smolik A, Stokłosa F. Zmiany kształtu kręgosłupa u sportowców. Kultura Fizyczna. 1959; 5: 11 - 21. Polish.
} 
The difference in shoulder height can be up to 2.5 centimeters. It is worth emphasizing that in fencers the different formation of the shape of the spine in the frontal plane while assuming the same, asymmetrical body positions, shows individual reactions to a similar stimulus.

The discipline, second most numerous in terms of the frequency of lateral curvatures of the spine is weight lifting, although it requires symmetry in the work of the upper limbs. However, the low location of the bend suggests a link between this curvature and the asymmetrical scissor style used in the toss technique. ${ }^{23}$

The lateral curvature of the spine is relatively rarely seen in speed skaters, despite the fact that they always deviate in the same direction on curves..

In archery, the necessity to adopt the correct posture before each string draw is undoubtedly a positive factor, shaping proper reflexes. On the other hand, the work of the back muscles, especially the muscles connecting the scapular with the spine, is asymmetrical. Hence, in professional archers, cases of thoracic scoliosis are not uncommon. Nevertheless, archery is recommended as a complementary sport, especially in disciplines where the superficial muscles of the back work in the position of the distance between the insertions, i.e. in basketball or cycling. The studies of Słoniewski and Łagan confirm the tendency for the asymmetric positioning of the shoulder girdle and the thoracic part of the spine in archers. ${ }^{24}$ The authors emphasize the fact that the observed asymmetries have two sources. The first results from the characteristics of the movement, the second is a consequence of the specificity of the adopted training methods and can be modified, thus minimizing the negative influences. They state that in the training process it is important to make people aware of the complexity of the movement mechanism of the shoulder girdle, which allows for the proper selection of general development, strength and fitness programs in order to maintain muscle balance and prevent injuries. In order to avoid this type of injury, the training methods include, first of all, the current control of the system by the trainer, balance exercises using the bow and other auxiliary elements, and technical exercises aimed at teaching proper reflexes.

In the studies by Sławińska, Rożek and Ignasiak from 2004, the parameters of the torso were assessed using the Moire method. ${ }^{25}$ A group of almost 400 young athletes between 11 and 15 years of age, of both genders, was subjected to it. Most of the respondents practiced running disciplines (88\%). It was found that among children from sports classes more often than in the control population, there was a deviation of the spinous processes from the vertical line, asymmetry of the position of the scapulars and the pelvis. In all the compared groups, there was a significant percentage of children with asymmetry of the waist triangles - this was the only parameter among the respondents with a higher incidence rate of asymmetry, both in boys and girls from the control group than in the sports group. Moreover, boys in the control group were more likely to have asymmetric shoulder positions. The authors formulated the following conclusion: in terms of most of the analysed parameters, early sports specialisation contributes to an increase in asymmetry within the torso.

\footnotetext{
${ }^{23}$ Smolik A, Stokłosa F. Zmiany kształtu kręgosłupa u sportowców. Kultura Fizyczna. 1959; 5: 11 - 21. Polish.

${ }^{24}$ Słoniewski J, Łagan S. Asymetryczne wady postawy w obrębie obręczy barkowej i w kończynach górnych u zawodników trenujących łucznictwo oraz sposoby ich minimalizacji. (W:) Aktualne Problemy Biomechaniki. 2010; 4: 167 - 172. Polish.

${ }^{25}$ Sławińska T, Rożek K, Ignasiak Z. Asymetria ciała w obrębie tułowia dzieci wczesnej specjalizacji sportowej. Medycyna Sportowa. 2006; 2(6), 22: 97 - 100. Polish.
} 


\section{Changes in the arch of the feet during the process of sports training}

When discussing the issues of posture defects in athletes, one should also mention the changes in the feet. It is known that a slight reduction in the longitudinal arch of the foot does not directly affect the fitness and efficiency of the body. ${ }^{26}$ However, it may affect the correct positioning of the pelvis in the sagittal and frontal planes, causing secondary changes in the physiological curves of the spine and scoliosis. The lack of a sufficiently high dynamic arch of the foot causes overloads in the area of the knee and lumbar spine joints. This accelerates the rate of degenerative changes.

Dynamic loads, even to a significant degree - among high and long jumpers, runners, footballers, basketball players, wrestlers, cyclists - do not cause adverse changes in the bone and ligament system of the foot. There was no tendency to lower the longitudinal arc in athletes from these disciplines ${ }^{2728}$. Slightly worse foot parameters were found in boxers and skiers. The longitudinal arch among these athletes tends to decrease in the following years of training, but it is better than in the group of non-training people ${ }^{29}$. The group of wrestlers has relatively the worst feet. However, it should be emphasized that despite the reduced longitudinal arch in this group of athletes, wrestlers' feet are fully functional. ${ }^{30}$

Most researchers dealing with the phenomenon of flat feet emphasize the role of the factor which is body weight, in shaping the longitudinal arch of the foot. The players of the disciplines in which the increased mass plays a major role usually have worse arches of the feet $^{31}$.

Dancers have numerous cases of hollow feet, i.e. feet with a very high longitudinal arch. ${ }^{32}$ This is a consequence of the development of strong plantar muscles of the foot and the flexors of the long fingers, necessary for point dancing. A dangerous disadvantage from the point of view of foot mechanics is hallux valgus, which occurs in almost $90 \%$ of the examined girls - students of ballet schools. This has serious health consequences, including exclusion from the profession of a dancer.

\footnotetext{
${ }^{26}$ Ignasiak Z, Kurowska J, Sławińska T. Morfologia stopy a sprawność fizyczna w okresie pokwitania. AWF Wrocław. 1987; 47: 285 - 292. Polish.

${ }^{27}$ Kuraś Z. Czynnościowe badania stopy u średnio i długodystansowców. Kultura Fizyczna. 1958; 12: 567. Polish.

${ }^{28}$ Łapka K. Próba oceny wpływu sportu wyczynowego na morfologiczno - czynnościowy stan stóp zawodników w niektórych dyscyplinach sportowych. AWF Warszawa. 1973; praca magisterska. Polish.

${ }^{29}$ Pawlaczyk L, Szmyt J. Zmiany wysklepienia stopy pod wpływem uprawiania narciarstwa. Kultura Fizyczna. 1958; 5: 799 - 801. Polish.

${ }^{30}$ Ślężyński J, Dębska H. Badania plantograficzne czołowych zapaśników świata. Wychowanie Fizyczne i Sport. 1977; 1. Polish.

${ }^{31}$ Ciechomski K, Kozłowski B. Stopa płaska w świetle badań czynnościowych. Polski Tygodnik Lekarski. 1979; 34 (9): $341-342$. Polish.

${ }^{32}$ Makarczuk A. Zmiany w obrazie morfologicznym stóp młodzieży uprawiającej taniec klasyczny, (W): Ontogeneza i promocja zdrowia $\mathrm{w}$ aspekcie medycyny, antropologii i wychowania fizycznego. Oficyna Wydawnicza Uniwersytetu Zielonogórskiego. 2002; 403 - 407. Polish.
} 


\section{Conclusions}

Increased motor activity does not unequivocally affect the incidence rates of correct and incorrect postures and practicing physical exercise does not ensure good posture. Onesided load that occurs in competitive sports affects the formation of physiological curves of the spine, most often causing their deepening. In disciplines characterised by asymmetry of movements, lateral curvatures of the spine occur more often than in others.

In order to achieve a posture considered to be correct, in addition to general development and sports result-oriented exercises, it is necessary to consciously shape and correct it. ${ }^{33}$ This is especially important when working with children and youth. It should be remembered that the susceptibility of the spine to changes in the shape of curves is different and depends on age. Wolański studied the so-called critical periods of posturogenesis among Warsaw youth and stated that the most dangerous age is between 12 and 15 for boys and between 10 and 13 for girls. ${ }^{34}$ It is then that the thoracic and lumbar curves are characterised by the greatest lability. They are very often deepened, which the author explains, among others changes in body proportions, i.e. elongation of the lower limbs. The commencement of professional training often takes place during this period, therefore, compensatory exercises should be its permanent element.

\section{Literature}

1. Barczyk - Pawelec K, Giemza C, Jastrzębska R, Hawrylak A, Kaczkowska A. Kształt krzywizn przednio - tylnych kręgosłupa w płaszczyźnie strzałkowej dziewcząt uprawiających piłkę ręczną. Acta Bio - Optica et Informatica Medica. 2012; 4 (18): 237 242.

2. Ciechomski K, Kozłowski B. Stopa płaska w świetle badań czynnościowych. Polski Tygodnik Lekarski. 1979; 34 (9): 341 - 342.

3. Chobocka E. Ćwiczenia wyrównawcze dla hokeistów, siatkarzy i piłkarzy nożnych. Wychowanie Fizyczne i Higiena Szkolna. 1988; 6: 187 - 190.

4. Chrzanowska M, Chojnacki K. Z badań nad stanem postawy ciała i sprawności fizycznej studentów. Kultura Fizyczna. 1976; 12; 24 - 36.

5. Fugiel J, Sławińska T. Postawa ciała dzieci wczesnej specjalizacji sportowej. Antropomotoryka. 2011; 53: s. 79 - 83.

6. Ignasiak Z, Kurowska J, Sławińska T. Morfologia stopy a sprawność fizyczna w okresie pokwitania. AWF Wrocław. 1987; 47: 285 - 292.

7. Iwanowski W. Pływanie korekcyjno - lecznicze w przypadkach bocznych skrzywień kręgosłupa. Wyd. Uniwersytetu Szczecińskiego. 1997. 47 - 51.

8. Kasperczyk T. Wady postawy ciała. Wyd. Kacper - Kraków. 1995.

9. Kuraś Z. Czynnościowe badania stopy u średnio i długodystansowców. Kultura Fizyczna. 1958; $12: 567$.

10. Kutzner - Kozińska M. (red.) Proces korygowania wad postawy. AWF Warszawa. 2001.

\footnotetext{
${ }^{33}$ Chobocka E. Ćwiczenia wyrównawcze dla hokeistów, siatkarzy i piłkarzy nożnych. Wychowanie Fizyczne i Higiena Szkolna. 1988; 6: 187 - 190. Polish.

${ }^{34}$ Wolański N. Krytyczny wiek w kształtowaniu się postawy ciała. Chirurgia Narządów Ruchu. 1958; 23(2): 129

-133 . Polish.
} 
11. Łapka K. Próba oceny sportu wyczynowego na morfologiczno - czynnościowy stan stóp zawodników w niektórych dyscyplinach sportowych. AWF Warszawa. 1973. praca magisterska.

12. Makarczuk A. Zmiany w obrazie morfologicznym stóp młodzieży uprawiającej taniec klasyczny. (W): Ontogeneza i promocja zdrowia w aspekcie medycyny, antropologii i wychowania fizycznego. Oficyna Wydawnicza Uniwersytetu Zielonogórskiego; 2002: $403-407$.

13. Makarczuk A, Kaźmierczak A. Wpływ sportu wyczynowego na postawę ciała. Aktywność ruchowa ludzi w różnym wieku. PTNKF Szczecin. 2004; 8: 248 - 254.

14. Pawlaczyk L, Szmyt J. Zmiany wysklepienia stopy pod wpływem uprawiania narciarstwa. Kultura Fizyczna. 1958; 5: 799 - 801.

15. Słoniewski J, Łagan S. Asymetryczne wady postawy w obrębie obręczy barkowej i w kończynach górnych u zawodników trenujących łucznictwo oraz sposoby ich minimalizacji. (W:) Aktualne Problemy Biomechaniki. 2010; 4: 167 - 172.

16. Smolik A, Stokłosa F. Zmiany kształtu kręgosłupa u sportowców, Kultura Fizyczna. 1959; 5: $11-21$.

17. Sonelski W, Sas - Nowosielski K. Trening wspinaczkowy dzieci i młodzieży. (W:). Sonelski W, Sas - Nowosielski K. Wspinaczka halowa. Vademecum. Polski Związek Alpinizmu. Warszawa. 1999. 61 - 68.

18. Stasiak J, Wierzbicka A. Kształtowanie się fizjologicznych krzywizn kręgosłupa u dzieci 8 - letnich, uprawiających pływanie na tle rówieśników niepływających. Lider. 1992; 9: $64-72$.

19. Ślężyński J, Dębska H. Badania plantograficzne czołowych zapaśników świata. Wychowanie Fizyczne i Sport. 1977; 1.

20. Świderska K. Zdrowie tancerzy. Warszawa. 1995.

21. Wojtków M, Korcz K, Szotek S. Ocena postawy ciała i symetrii obciążenia stóp u zawodników uprawiających strzelectwo sportowe. Aktualne Problemy Biomechaniki. 2016; 10: 91 - 98 .

22. Wolański N. Krytyczny wiek w kształtowaniu się postawy ciała. Chirurgia Narządów Ruchu. 1958; 23(2): 129 - 133.

23. Wolański N. Rozwój biologiczny człowieka. PWN. 2005.

24. Zeyland - Malawka E. O kryteriach oceny postawy. (W:) Postawa ciała człowieka i metody jej oceny. (red.) J. Ślężyński. AWF Katowice. 1992. 